\title{
Fruit Production Characteristics of 'Pawnee' Pecan
}

\author{
Michael W. Smith ${ }^{1}$ \\ Department of Horticulture and Landscape Architecture, 360 Agricultural \\ Hall, Oklahoma State University, Stillwater, OK 74078
}

Additional index words. Carya illinoinensis, yield, fruit quality, nut, alternate bearing

\begin{abstract}
Yield and selected nut quality characteristics were monitored on hedge pruned 'Pawnee' pecan [Carya illinoinensis (Wangenh.) K. Koch.] trees over a 5-year period to characterize optimum production defined as equal crops 2 successive years. Previous year yield was linearly or quadratically related to current-season yield in three of four instances. Optimum yield ranged from $18 \mathrm{~kg} /$ tree to $29 \mathrm{~kg} /$ tree among years. Weight/nut, weight/kernel, and percent kernel were negatively related to yield/tree. Weight/nut and weight/kernel were more closely related to yield/tree than percent kernel, indicating that as cropload increased, shell weight and kernel weight were disproportionately affected. Increasing croploads reduced kernel weight more than shell weight, thus reducing the correlation between percent kernel and yield. Twenty-seven percent of the trees in the study produced greater than average yields with a lower than average alternate bearing index.
\end{abstract}

Alternate bearing was recently identified as a key component limiting expansion of the pecan industry by producers, shellers, and processors (Smith and Weckler, 2011). Pecan alternate-bearing theories have undergone modification as additional data have become available. Current theory concerning flowering regulation of angiosperm fruit trees (Bangerth, 2009) and specifically pecan (Wood, 2011) states that the level-one signal of the autonomous floral pathway is florigen [a mobile flowering locus T protein (Yang et al., 2007)]. The level-two floral signal appears to involve long-distance signals that engage histones affecting chromatin configuration and thus accessibility to particular genes for transcription (Kouzarides, 2007; Nelissen et al., 2007). Phytohormones are candidates for long-distance signals such that gibberellins and auxin inhibit floral induction, whereas cytokinins promote floral induction (Bangerth, 2009; Wood, 2011). In pecan, non-structural carbohydrate concentrations in roots were implicated in pistillate flower differentiation (post-floral induction) (Malstrom, 1974; Smith and Waugh, 1938; Sparks and Brack, 1972; Wood, 1989, 1991; Worley, 1979), but later work demonstrated that abundant stored non-structural carbohydrates were not related to return bloom (Rohla et al., 2007a, 2007b; Smith et al., 2007).

\footnotetext{
Received for publication 20 Jan. 2012. Accepted for publication $23 \mathrm{Feb} .2012$.

Funded by the Oklahoma Agricultural Experiment Station, Samuel Roberts Noble Foundation, Hauani Creek Ranch, Montz Pecan Orchard, Oklahoma Pecan Growers' Association, Texas Pecan Board, and the USDA Crop Germplasm Committee.

I gratefully acknowledge the support and assistance of Becky Cheary, Tim Montz, and Jake Montz and the use to the Montz Pecan Orchard for this project. Approved for publication by the Oklahoma Agricultural Experiment Station.

${ }^{1}$ To whom reprint requests should be addressed; e-mailmike.smith@okstate.edu.
}

induced meristems, avoiding meristem reversion to the vegetative state and favoring pistillate flower differentiation. Cultivars receiving inadequate vernalization may flower through the autonomous pathway; however, reversion of induced meristems should be greater resulting in less production.

Several cultural practices have been developed to reduce pecan alternate bearing. These include management of the tree canopy for light interception (Hinrichs, 1961; Lombardini, 2006), mineral nutrition (Smith, 2010; Smith et al., 1985), groundcover vegetation (Smith, 2011), water (drainage, conservation, and irrigation) (Kallestad et al., 2006; Smith and Bourne, 1989), pest control (Mulder et al., 2011), and cropload (Reid et al., 1993; Smith and Gallott, 1990; Smith et al., 1993). Cultivar selection also has a major impact on alternate bearing (Conner and Worley, 2000). 'Pawnee' is a popular cultivar grown throughout the entire pecangrowing region because of its early-season maturity and large fruit size (Thompson and Grauke, 2000). However, it has developed a reputation among producers for alternate bearing. Alternate-bearing pecan cultivars typically produced a lower percentage of shoots with fruit if that shoot bore fruit the previous year compared with shoots that were vegetative (Rohla et al., 2007b). The opposite was true for cultivars that tend to bear uniform crops among years. Data indicate that the fruit-bearing characteristics of 'Pawnee' represent a cultivar that should have relatively uniform production (Rohla et al., 2007a). However, even cultivars with low alternate-bearing tendencies will produce an excessive crop resulting in few flowers and fruit the next year unless fruit were adequately thinned. An objective of this study was to determine the maximum
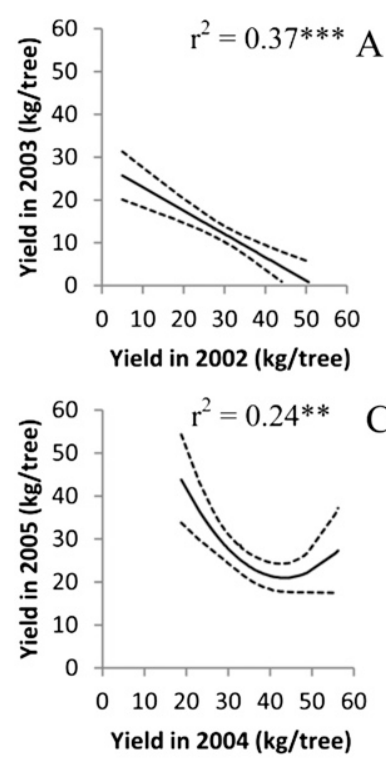

Fig. 1. Correlations between the previous year yield with the subsequent year yield of 'Pawnee' pecan Correlations were calculated for (A) 2002 with 2003 through (D) 2005 with 2006. Coefficients of determination were nonsignificant (NS) or significant at $1 \%(* *)$ or $0.1 \%(* * *)$. Dotted lines represent $95 \%$ confidence bands.

Work on Arabidopsis indicated that a fundaautonomous pathways was delivery of sugar to the shoot apex (van Nocker, 2001). Thus, nonfloral regulation (causing reversion of the induced meristem) when their concentrations requisite sugar to the induced (reproductive) as a requirementization has been sugges Amling and Amling, 1983). In Arabidopsis, verge on the negative regulation of ing locus C (Ausín et al., 2004). In pecan, vernalization may enhance sugar transport to
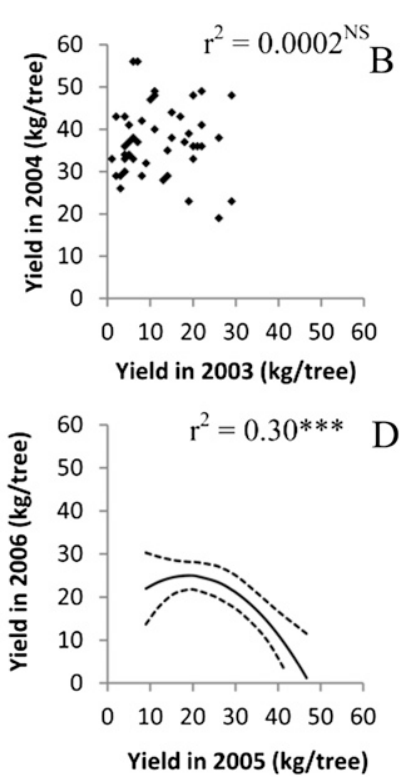

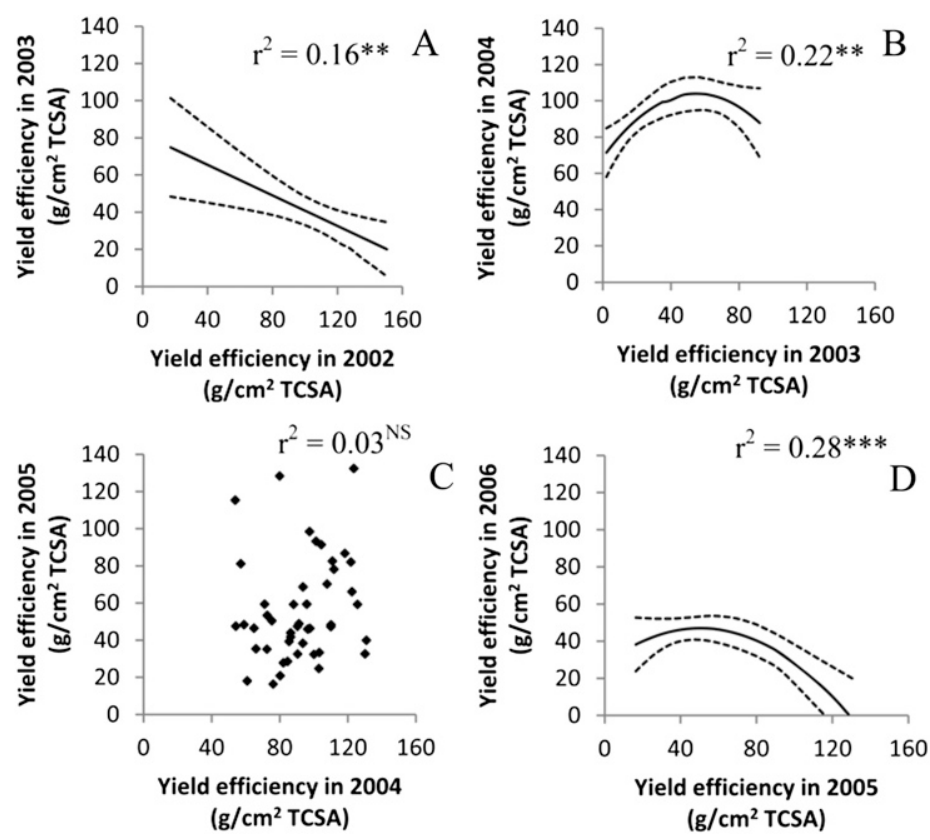

Fig. 2. Correlations between previous year's yield efficiency $\left[\mathrm{g} / \mathrm{cm}^{2}\right.$ trunk cross-sectional area (TCSA)] with the subsequent year's yield efficiency of 'Pawnee' pecan. Correlations were calculated for (A) 2002 with 2003 through (D) 2005 with 2006. Coefficients of determination were nonsignificant (NS) or significant at $1 \%(* *)$ or $0.1 \%(* * *)$. Dotted lines represent $95 \%$ confidence bands.

cropload 'Pawnee' trees in this study could carry and return a similar crop the next year. In addition, selected nut quality characteristics were correlated with cropload.

\section{Materials and Methods}

'Pawnee' on open-pollinated seedling 'Elliott' rootstocks were 14 years old when the study was initiated. Tree were spaced $12.2 \mathrm{~m} \times 12.2 \mathrm{~m}$, irrigated by microsprinkler, and were planted on a Teller sandy loam soil (fine-loamy, mixed, thermic, Udic Argiustoll). The soil $\mathrm{pH}$ was 7.9 in the upper $15 \mathrm{~cm}$ and 7.2 in the 15 - to $30-\mathrm{cm}$ level. Rows were oriented north-south and were hedge-pruned annually on the east and west sides 2.5 to $3 \mathrm{~m}$ from the trunk and the top 8.5 to $9.5 \mathrm{~m}$ tall. The orchard floor was maintained vegetationfree throughout the growing season with multiple applications of glyphosate [N(phosphonomethyl) glycine] in the form of its potassium salt applied at $408 \mathrm{~g} \cdot \mathrm{ha}^{-1}$ a.i. No winter cover crops were used, but coolseason vegetation was allowed to grow during the winter. Trees received $\approx 160 \mathrm{~kg} \cdot \mathrm{ha}^{-1}$ nitrogen $(\mathrm{N})$ annually from nitrate-contaminated irrigation water and had not received supplemental N application since 2002. Foliar applications of zinc sulfate $(36 \%$ zinc; $6.7 \mathrm{~kg} \cdot \mathrm{ha}^{-1}$ material) were applied annually beginning when the first leaf began to unfurl then at $\approx 2$-week intervals until applied five times during each growing season.

Forty-nine trees were monitored annually for 5 years. Trees were harvested, yield measured, and a random 40-nut sample was collected from each tree. Nut samples were collected from field-run nuts (before cleaning to remove light weight nuts) and analyzed for weight/nut, weight/kernel, and kernel percentage. Trunk diameter was measured annually at 1.4-m height while trees were dormant. An alternate-bearing index was calculated for each tree using the equation:

$$
\begin{aligned}
I= & 1 /(\mathrm{n}-1)\left[\left|\left(\mathrm{a}_{2}-\mathrm{a}_{1}\right)\right| /\left(\mathrm{a}_{2}+\mathrm{a}_{1}\right)\right. \\
& +\left|\left(\mathrm{a}_{3}-\mathrm{a}_{2}\right)\right| /\left(\mathrm{a}_{3}+\mathrm{a}_{2}\right) \\
& \left.+\bullet \bullet \bullet\left|\left(\mathrm{a}_{\mathrm{n}}-\mathrm{a}_{\mathrm{n}-1}\right)\right| /\left(\mathrm{a}_{\mathrm{n}}+\mathrm{a}_{\mathrm{n}+1}\right)\right]
\end{aligned}
$$

where $I$ was the alternate-bearing index; $\mathrm{n}$ was the number of years; and $a_{1}, a_{2}$, and $a_{n}$ were yields of corresponding years (Pearce and Dobersek-Urbanc, 1967). The alternatebearing index ranged from 0 to 1 ; a higher index indicates more alternate bearing. Yield efficiency was calculated by dividing the yield by the trunk cross-sectional area.

Linear and quadratic equations were fitted to data using least squares techniques with 95\% confidence bands calculated (Draper and Smith, 1966). Previous season yield/tree was correlated with current-season yield/tree from 2002 through 2006. Current-season yield/tree was also correlated with weight/ nut, weight/kernel, and percent kernel. Previous season yield efficiency (yield/trunk cross-sectional area) was correlated with current-season yield efficiency.

Superior trees among the 49 observed trees were determined by those with above average cumulative yield and below average alternate-bearing index. Trees that occurred in both categories they were identified as superior (Wood, 1989).

\section{Results}

Previous season yield was linearly related to current-season yield 1 year and curvilinearly related 2 years (Fig. 1). In 2003, yield/tree was not significantly related to 2004 yield/ tree, probably because the 2003 yield was atypically low resulting in most trees having a large 2004 crop. Significant regressions of previous and current yield accounted for $24 \%$ to $37 \%$ of the variation in the data.

Regressions of previous year with currentyear yield efficiency were significant in three of four cases (Fig. 2). Trends were linear in one instance and curvilinear in the other two cases. Coefficients of determination indicated that the significant regressions accounted for $16 \%$ to $28 \%$ of the data variation.

Regressions of yield/tree with weight/nut, weight/kernel, and percent kernel were significant in all cases (2002-2006; Figs. 3-7). Coefficients of determination were as large as or larger for weight/kernel than weight/nut in all but one instance. Relationships with yield for weight/nut or kernel were linear during 2002, 2004, and 2006 and curvilinear in 2003 and 2005 .

Current-season yield was linearly related to percent kernel in 2002, 2003, and 2004 and curvilinearly related in 2005 and 2006 (Figs. 3-7). Coefficients of determination for yield with percent kernel ranged from 0.13 to 0.30 and were lower than those for yield with weight/nut or weight/kernel.

Trees with a low alternate-bearing index produced the greatest 5-year cumulative yield (Fig. 8). Those with an intermediate alternatebearing index $(0.4-0.5)$ had the lowest yields. As the alternate-bearing index increased beyond intermediate ratings, cumulative yield increased, indicating that a very large crop followed by a small crop produced nearly as much cumulative yield as trees with a low alternate index.

\section{Discussion}

Yield the previous year accounted for $24 \%$ to $37 \%$ of the variation in the currentseason yield (Fig. 1). This is not surprising because Sparks (1996) found that previous year nut production only accounted for $6 \%$ of a model predicting current-season Georgia pecan production. If Georgia's acreage increase was eliminated from the model, previous year nut production accounts for $12 \%$ of the model predicting Georgia's currentyear production. The coefficients of determination in this study were higher because they represent recurring yields on the same trees, whereas those in the Georgia model use annual production from the entire state.

One of the objectives of this study was to determine the optimum cropload (defined as the same production each year) for 'Pawnee' trees in this study. The yield that returned the same yield the next year was $18 \mathrm{~kg} / \mathrm{tree}, 29$ $\mathrm{kg} /$ tree, and $24 \mathrm{~kg} /$ tree in 2002, 2004, and 2005 , respectively. The estimate for the optimum crop varied $\approx 60 \%$ among years. Factors affecting the optimum cropload include tree size, environmental conditions, and pests. Trees were smaller in 2002 compared with 2004 and 2005; thus, a smaller optimum yield would be expected on smaller 

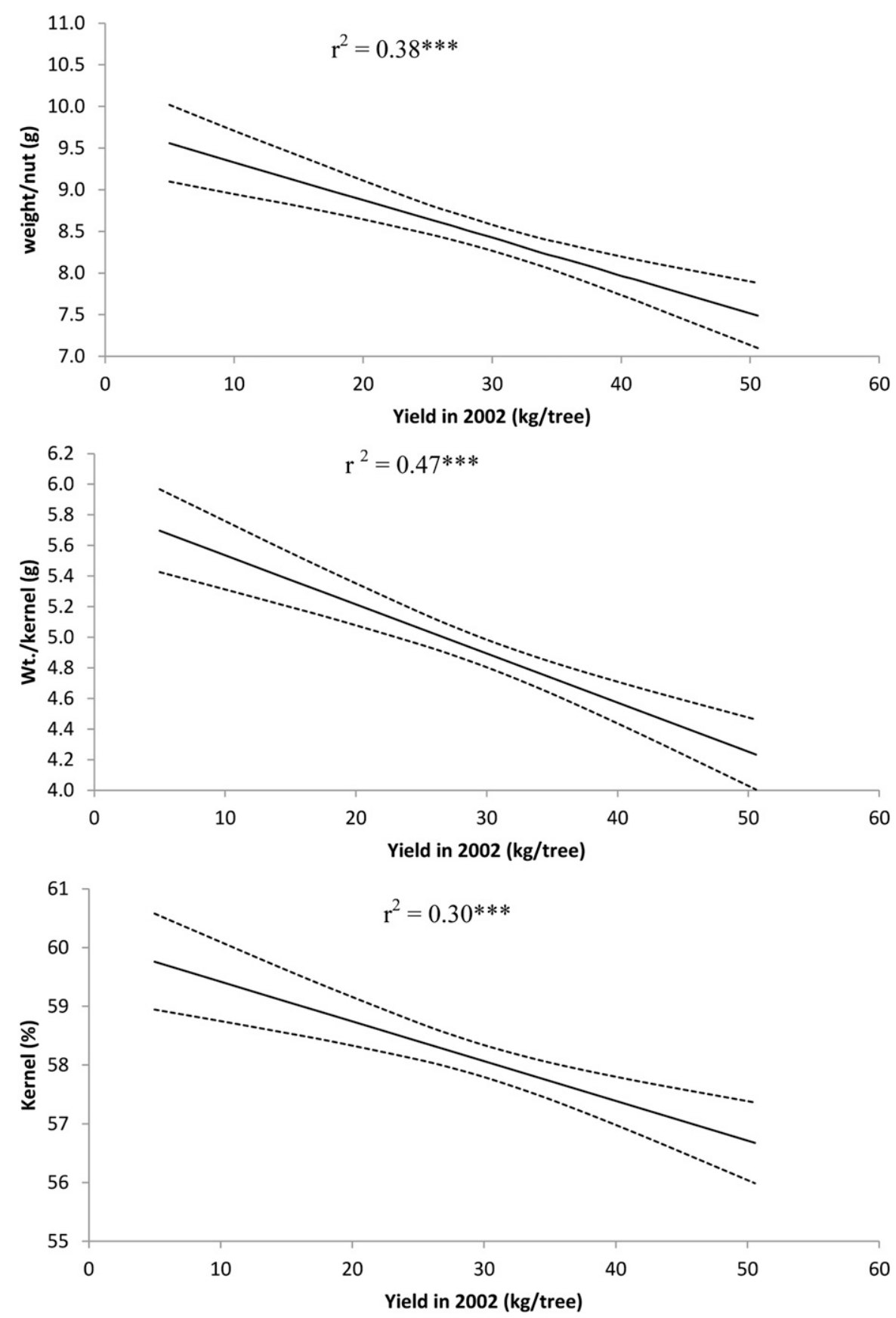

Fig. 3. Correlations between yield in 2002 with weight/nut, weight/kernel, and kernel percentage of 'Pawnee' pecan. Coefficients of determination were significant at $0.1 \%(* * *)$. Dotted lines represent $95 \%$ confidence bands.

trees. Pests, both arthropods and disease, were not a significant problem in this wellmanaged orchard. Optimum yield in 2004 and 2005 were relatively close only differing by $21 \%$. Differences in the apparent optimum cropload during this period reflect different environmental conditions during the growing season because canopies were maintained approximately the same size by hedge-pruning. Sparks (1996) found several environmental variables to be as important as or more important than previous-year yield in predicting the current crop.

Coefficients of determination for previous year yield efficiency with current-year yield efficiency ranged from 0.16 to 0.28 , account- ing for less variability than regressing for previous year yield/tree with current yield/ tree (0.24-0.37) (Figs. 2 and 3). Trunk crosssectional area of pecan trees with minimal pruning was closely related to canopy volume and surface area (Smith, 2008). Therefore, a closer correlation between the previous year and current year would be expected using yield efficiency rather than yield/tree. However, trees in this study were hedge-pruned, reducing the correlation between trunk size and the canopy. Trunks continued to grow annually, but the canopies were maintained approximately the same size by pruning; thus, adjusting yield by trunk size becomes unacceptable in hedge-pruned orchards.
The most productive trees in the study were those with a low alternate-bearing index (Fig. 8). Trees with a high alternate-bearing index (i.e., very high yield followed by low yield) had nearly as much cumulative yield as those with a low alternate-bearing index. Because nut characteristics were consistently linked to tree yield such that as yield increased, nut quality decreased (Figs. 3-7), trees with a low alternate-bearing index and a high cumulative yield are extremely desirable.

Average cumulative yield and alternatebearing index were determined, and then trees were selected in the top half of cumulative yield and lower half of alternate bearing. There were 13 of $49(27 \%)$ trees in both 

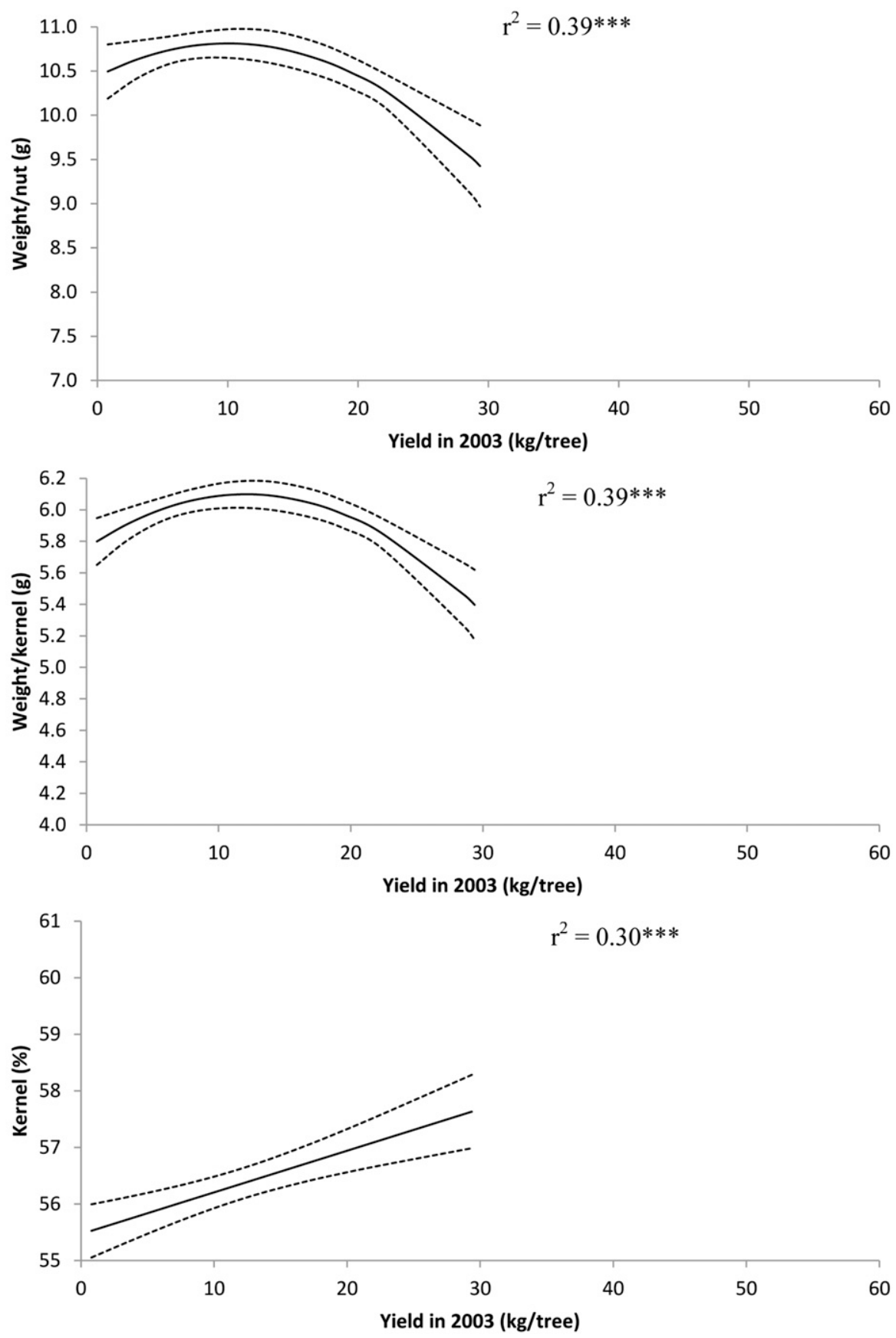

Fig. 4. Correlations between yield in 2003 with weight/nut, weight/kernel, and kernel percentage of 'Pawnee' pecan. Coefficients of determination were significant at $0.1 \%(* * *)$. Dotted lines represent $95 \%$ confidence bands.

categories that were designated as superior. Wood (1989) reported $43 \%$ of 'Stuart' and $14 \%$ of 'Schley' pecan trees on an unknown seedling rootstock were designated as superior using the same criteria. He attributed the superiority of these trees to rootstock. In this study, the soil was uniform; trees received the same cultural practices and were exposed to the same environmental conditions. Therefore, it is reasonable to credit the superior performance of the clonal 'Pawnee' scion to differences among the seedling 'Elliot' rootstocks.

Correlations between yield and kernel percentage were usually lower than the correlations with weight/nut or weight/kernel (Figs. 3-7). This indicates that, as yield/tree increases, shell weight and kernel weight were not reduced at the same rate. Pecan fruit attain full size (volume) before deposition of cotyledonary material (Smith, 2009). Demand for available resources was minimal while fruit were growing in size and during shell lignification. However, because kernels develop in the latter part of the growing season, demand for carbohydrates and nutrients increases substantially and competition among developing fruit amplifies. Therefore, greater tree yields disproportionately impact kernel and shell weights, thus reducing the relationship between yield/tree and percent kernel more than with shell or kernel weights.

\section{Conclusions}

Uniform cropping among years with good nut quality was possible on 'Pawnee', but the optimum cropload was a moving target, probably reflecting changes in tree canopy size among years and environmental conditions during the growing season. The ability of 'Pawnee' to achieve uniform cropping between years with abundant production supports work (Rohla et al., 2007a) indicating that 'Pawnee' has characteristics of a low alternate-bearing cultivar (Rohla et al., 2007b). The alternate-bearing reputation of 'Pawnee' appears to be associated with inadequate fruit thinning when trees are overloaded (Smith and 

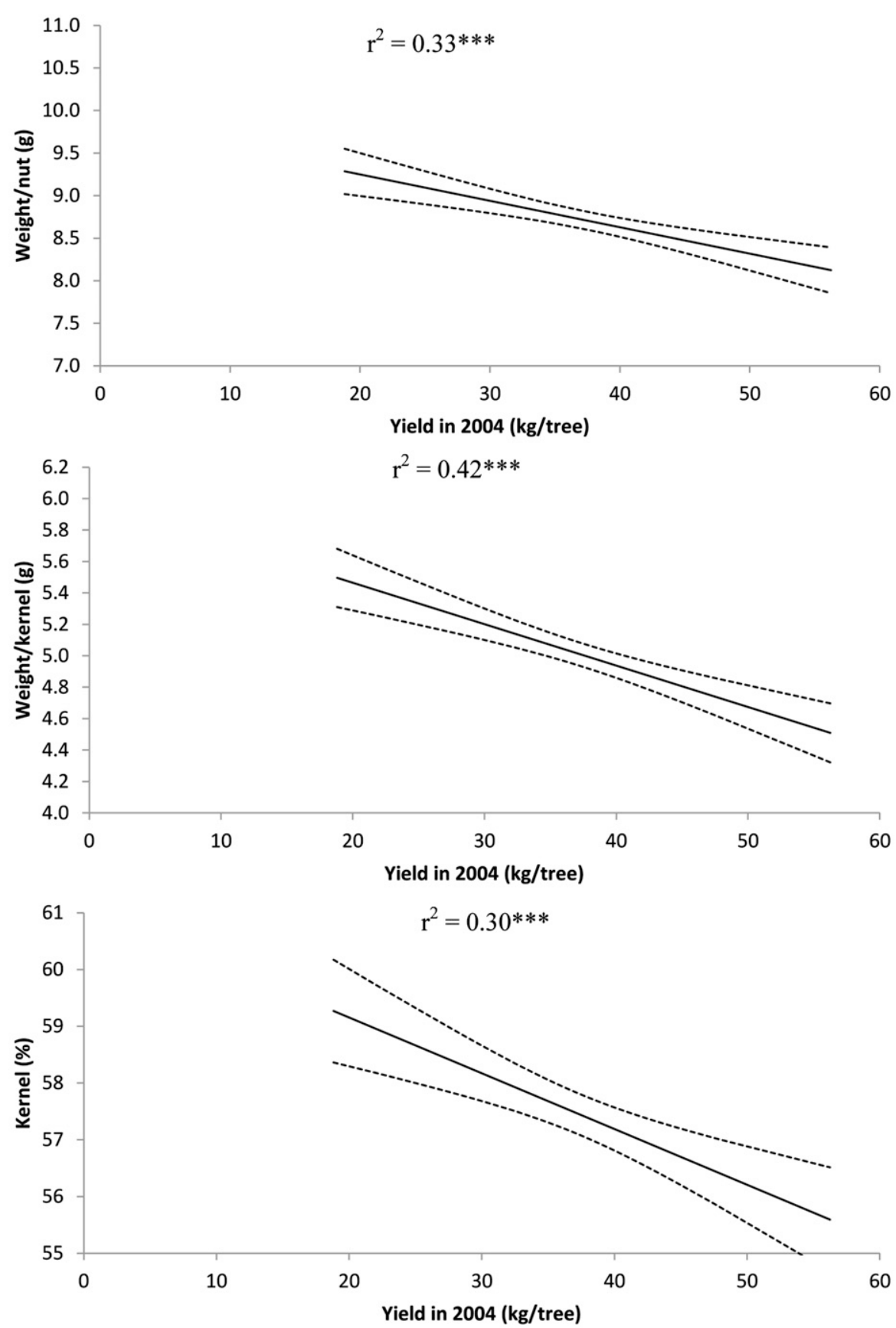

Fig. 5. Correlations between yield in 2004 with weight/nut, weight/kernel, and kernel percentage of 'Pawnee' pecan. Coefficients of determination were significant at $0.1 \%(* * *)$. Dotted lines represent $95 \%$ confidence bands.

Gallott, 1990) or erratic environmental conditions rather than an inability to produce fruit on shoots that previously bore fruit. Previous research suggested that a cropload of $65 \%$ to $70 \%$ of the shoots bearing fruit was recommended for a cultivar with similar nut size to achieve acceptable nut quality and return bloom (Smith et al., 1993). Observations indicate that this recommended cropload was reasonable to achieve the desired outcome with the normal environmental variations expected during the growing season.

Trees that yielded more with less alternate bearing have been identified in this study and elsewhere (Wood, 1989). Pecan orchards are normally planted with two planned tree thinnings (removal) to avoid excessive crowding causing shading that will reduce production. Even orchards managed by hedge-pruning eventually require tree thinning when compensatory growth becomes excessive and interior bearing branches are lost as a result of shading. Goff and Browne (2004) advocate tree removal based on certain tree criteria using productivity, pest susceptibility, limb breakage, cultivar, and tree health rather than thinning using a predetermined pattern. These data support selective tree thinning to increase orchard productivity and decrease alternate bearing.

\section{Literature Cited}

Amling, H.J. and D.A. Amling. 1983. Physiological differentiation of pistillate flowers of pecan and cold requirements for their initiation. J. Amer. Soc. Hort. Sci. 108:195-198.

Ausín, I., C. Alonso-Blanco, J.A. Jarillo, L. RuizGarcía, and J. Martínez-Zapater. 2004. Regulation of flowering time by FVE, a retinoblastomaassociated protein. Nat. Genet. 36:162-166.

Bangerth, K.F. 2009. Floral induction in mature, perennial angiosperm fruit trees: Similarities and discrepancies with annual/biennial plants and the involvement of plant hormones. Sci. Hort. 122:153-163.

Conner, P.J. and R.E. Worley. 2000. Alternate bearing intensity of pecan cultivars. HortScience 35:1067-1069.

Draper, N.R. and H. Smith. 1966. Applied regression analysis. Wiley, New York, NY.

Goff, B. and C. Browne. 2004. A method of dealing with overcrowded orchards. Proc. Southeastern Pecan Growers Assn. 97:77-82. 

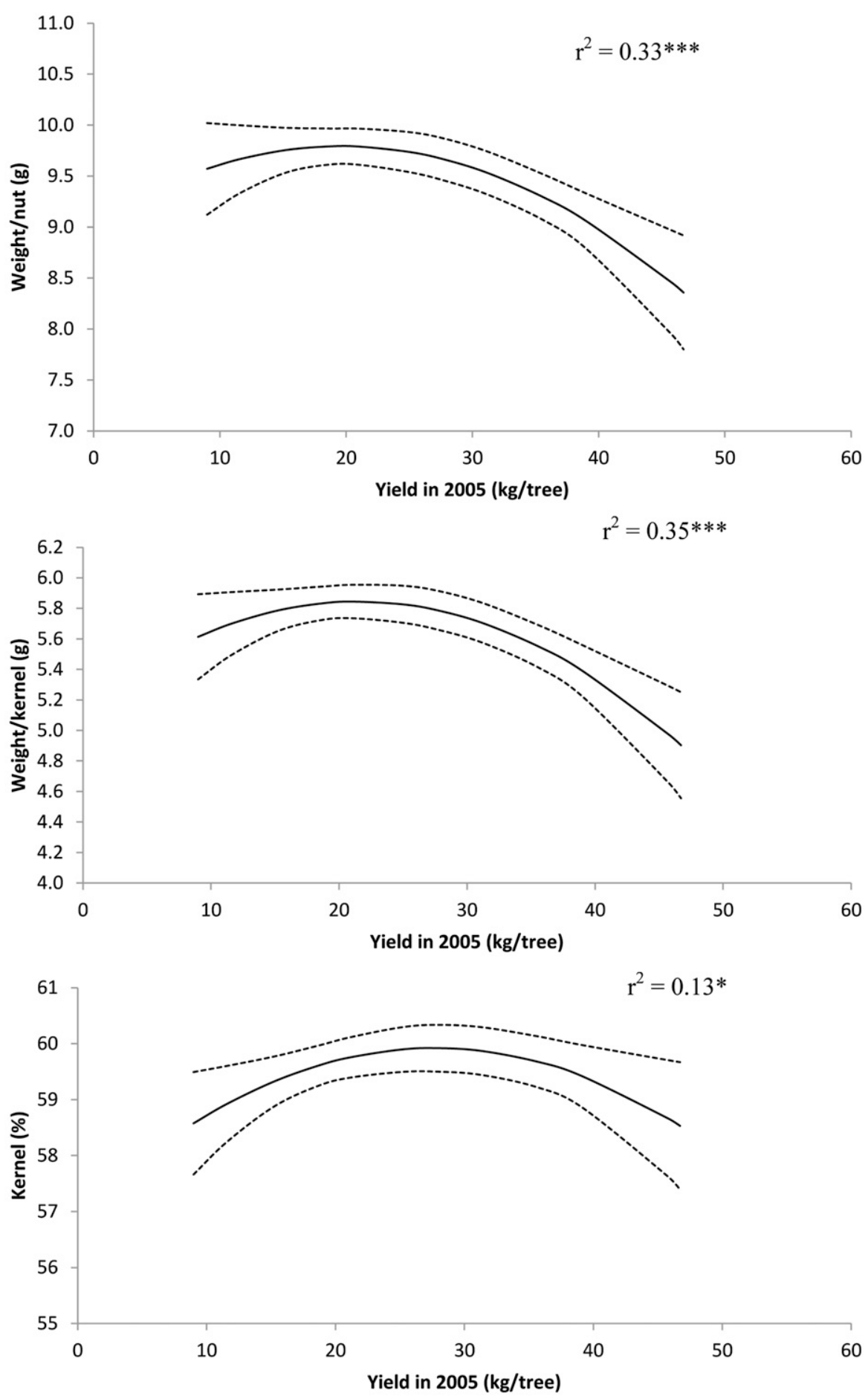

Fig. 6. Correlations between yield in 2005 with weight/nut, weight/kernel, and kernel percentage of 'Pawnee' pecan. Coefficients of determination were significant at $5 \%(*)$ or $0.1 \%(* * *)$. Dotted lines represent $95 \%$ confidence bands.

Hinrichs, H.A. 1961. The relationship of native pecan tree spacing to yield. Okla. Agric. Expt. Sta. Bul. B-574.

Kallestad, J.C., J. White, J.G. Mexal, and T.W. Sammis. 2006. Monitoring and management of pecan orchard irrigation: A case study. HortTechnology 16:667-673.

Kouzarides, T. 2007. Chromatin modifications and their function. Cell 128:693-705.

Lombardini, L. 2006. One-time pruning of pecan trees induced limited and short-term benefits in canopy light penetration, yield, and nut quality. HortScience 41:1469-1473.
Malstrom, H.L. 1974. The relationship of stored reserves to yield in mature pecan trees. Proc. Western Pecan Conf. 8:65-69.

Mulder, P., E. Stafne, and D. Smith. 2011. Commercial pecan insect and disease control -2011 . Okla. Coop. Ext. Curr. Rep. CR-6209.

Nelissen, H., T.M. Boccardi, K. Himanen, and M. Van Lijsebettens. 2007. Impact of core histone modifications on transcriptional regulation and plant growth. Crit. Rev. Plant Sci. 26:243-263.

Pearce, S.C. and S. Dobersek-Urbanc. 1967. The management of irregularity in growth and cropping. J. Hort. Sci. 42:295-305.
Reid, W., S.M. Huslig, M.W. Smith, N.O. Maness, and J.L. Whitworth. 1993. Fruit-removal time influences return bloom in pecan. HortScience 28:800-802

Rohla, C.T., M.W. Smith, and N.O. Maness. 2007a. Influence of cluster thinning on return bloom, nut quality, and concentrations of potassium, nitrogen, and non-structural carbohydrates in pecan. J. Amer. Soc. Hort. Sci. 132:158-165.

Rohla, C.T., M.W. Smith, N.O. Maness, and W. Reid. 2007b. A comparison of return bloom and nonstructural carbohydrates, nitrogen and potassium concentrations in moderate and severe 

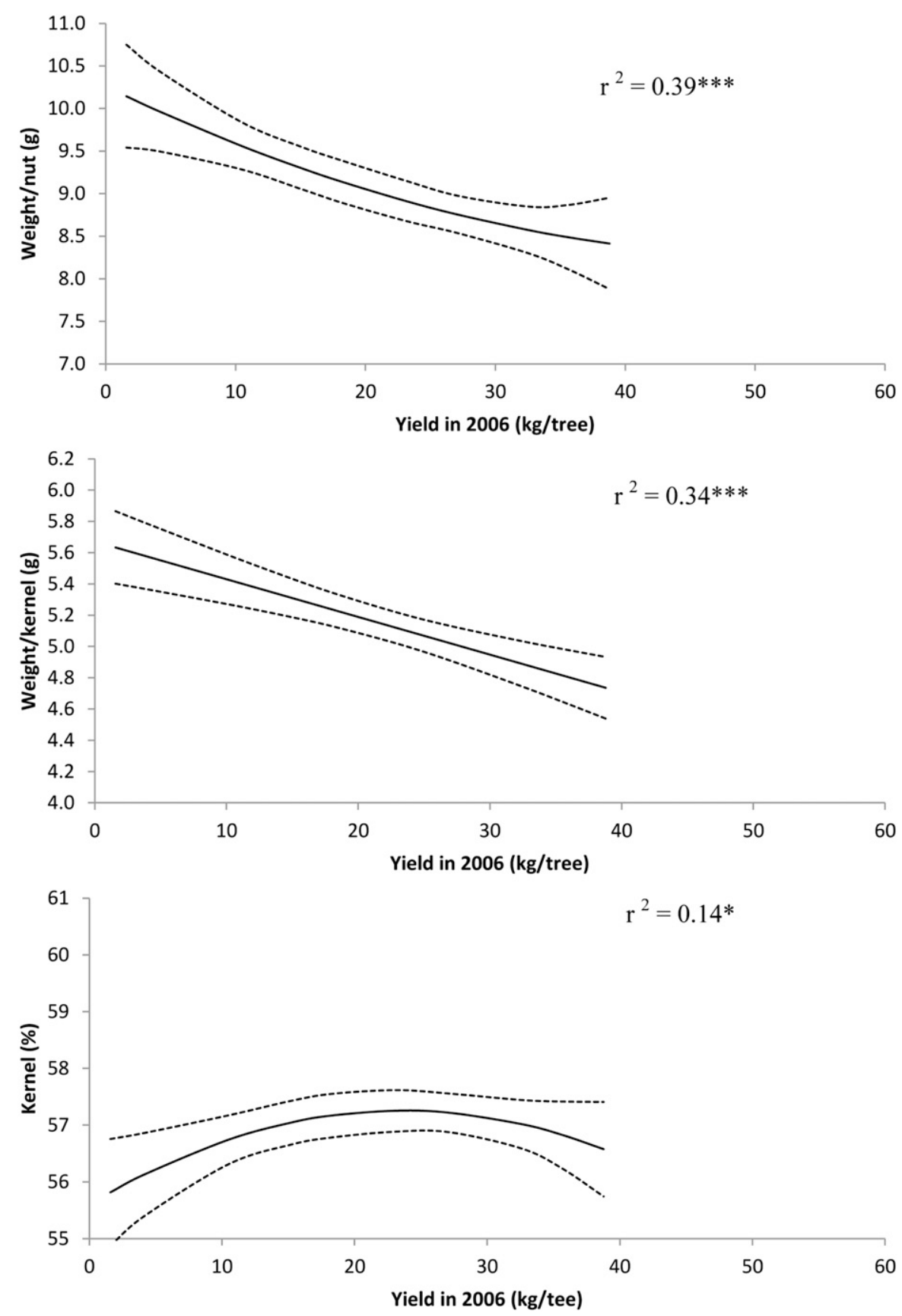

Fig. 7. Correlations between yield in 2006 with weight/nut, weight/kernel, and kernel percentage of 'Pawnee' pecan. Coefficients of determination were significant at $5 \%(*)$ or $0.1 \%(* * *)$. Dotted lines represent $95 \%$ confidence bands.

alternate-bearing pecan cultivars. J. Amer. Soc. Hort. Sci. 132:172-177.

Smith, C.L. and J.G. Waugh. 1938. Seasonal variations in the carbohydrate and nitrogen content of roots of bearing pecan trees. J. Agr. Res. 57:449-460.

Smith, M.W. 2008. Relationship of trunk size to selected canopy size parameters for native pecan trees. HortScience 43:784-786.

Smith, M.W. 2009. Partitioning phosphorus and potassium in pecan trees during high- and lowcrop seasons. J. Amer. Soc. Hort. Sci. 134:399404.

Smith, M.W. 2010. Relationship of leaf necrosis and defoliation to phosphorus and potassium concentrations in selected tissue and to certain fruit quality parameters of pecan. Sci. Hort. 125:117-122.
Smith, M.W. 2011. Pecan production increased by larger vegetation-free area surrounding the tree. Sci. Hort. 130:211-213.

Smith, M.W., P.L. Ager, and D.S.W. Endicott. 1985. Effect of nitrogen and potassium on yield, growth, and leaf elemental concentration of pecan. J. Amer. Soc. Hort. Sci. 110:446-450.

Smith, M.W. and R. Bourne. 1989. Effects of flooding pecan seedlings during dormancy, budbreak, and active growth. HortScience 24 81-83.

Smith, M.W. and J.C. Gallott. 1990. Mechanical thinning of pecan fruit. HortScience 25:414 416.

Smith, M.W., W. Reid, B. Carroll, and B. Cheary. 1993. Mechanical fruit thinning influences fruit quality, yield, return fruit set, and cold injury of pecan. HortScience 28:1081-1084.
Smith, M.W., C.T. Rohla, and N.O. Maness. 2007. Correlations of crop load and return bloom with root and shoot concentrations of potassium, nitrogen, and nonstructural carbohydrates in pecan. J. Amer. Soc. Hort. Sci. 132:44-51.

Smith, M.W. and P. Weckler. 2011. Industry meets to pinpoint research, extension priorities. Pecan South 44:14-18.

Sparks, D. 1996. A climatic model for pecan production under humid conditions. J. Amer. Soc. Hort. Sci. 121:908-914.

Sparks, D. and C.E. Brack. 1972. Return bloom and fruit set of pecan from leaf and fruit removal. HortScience 7:131-132.

Thompson, T.E. and L.J. Grauke. 2000. 'Pawnee' pecan. J. Amer. Pomol. Soc. 54:110-113.

van Nocker, S. 2001. The molecular biology of flowering. In: Janick, J. (ed.). Hort. Rev. 27:1-39. 


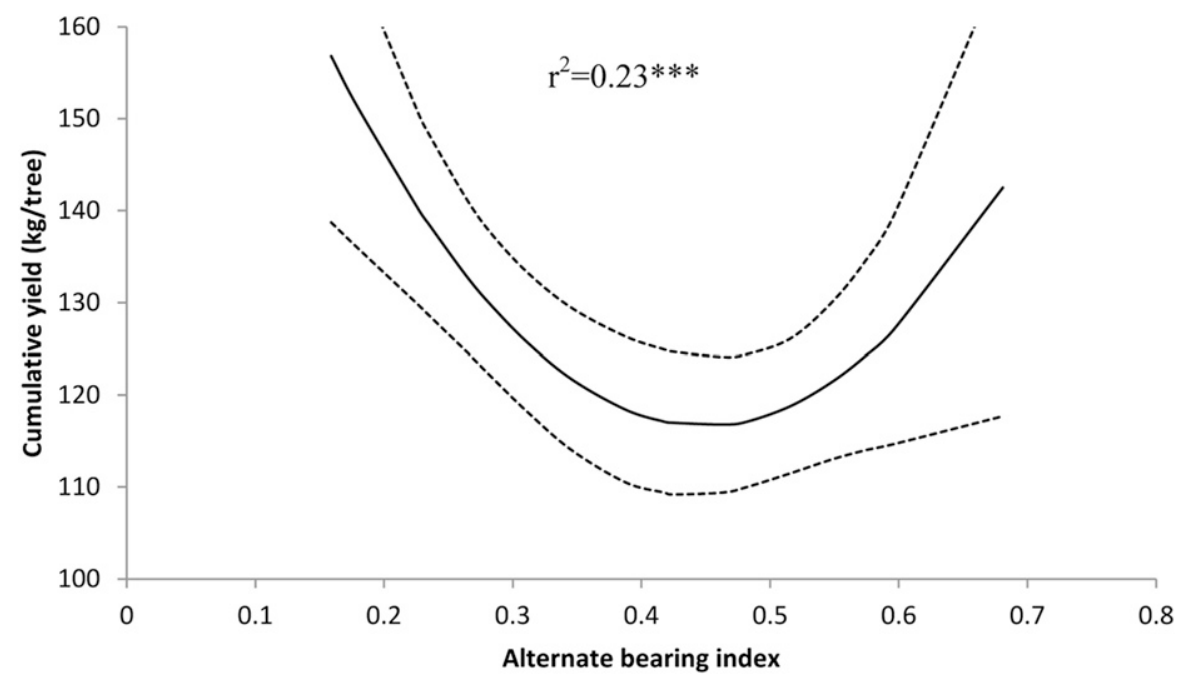

Fig. 8. The relationship between the alternate bearing index and cumulative yield of 'Pawnee' pecan from 2002 to 2006 . Coefficient of determination was significant at $0.1 \%(* * *)$. A lower index value indicates less variability among years in the yield. Dotted lines represent $95 \%$ confidence bands.

Wood, B.W. 1989. Pecan production responds to root carbohydrates and rootstock. J. Amer. Soc. Hort. Sci. 114:223-228.

Wood, B.W. 1991. Alternate bearing in pecan, p. 180-190. In: Wood, B.W. and J.A. Payne (eds.). Pecan husbandry: Challenges and opportunities.
Proc. First National Pecan Workshop, U.S. Dept. Agr., Agric. Res. Serv., ARS-96.

Wood, B.W. 2011. Influence of plant bioregulators on pecan flowering and implications for regulation of pistillate flower initiation. HortScience 46:870-877.
Worley, R.E. 1979. Fall defoliation date and seasonal carbohydrate concentration of pecan wood tissue. J. Amer. Soc. Hort. Sci. 104:195-199.

Yang, Y., J. Klejnot, X. Yu, X. Liu, and C. Lin. 2007. Florigen (II): It is a mobile protein. J. Integr. Plant Biol. 49:1665-1669. 